\title{
Macronutrient and Mineral Composition of Selected Traditional Rice Varieties in Sri Lanka
}

\author{
Amali Kulasinghe ${ }^{1}$, Gamini Samarasinghe ${ }^{2}$, Swarna Wimalasiri ${ }^{3}$, Renuka Silva ${ }^{4}$, \\ Terrence Madhujith ${ }^{5}$ \\ ${ }^{I}$ Department of Food Science \& Technology, Faculty of Agriculture, University of Peradeniya, Sri Lanka \\ ${ }^{2}$ Plant Genetic Resource Center, Gannoruwa, Sri Lanka \\ ${ }^{3}$ Department of Food Science \& Technology, Faculty of Agriculture, University of Peradeniya, Sri Lanka \\ ${ }^{4}$ Department of Applied Nutrition, Faculty of Livestock, Fisheries and Nutrition, Wayamba University, Sri \\ Lanka \\ ${ }^{5}$ Postgraduate Institute of Agriculture, University of Peradeniya, Sri Lanka \\ Corresponding Author's email: anupamakulasinghe@gmail.com
}

\begin{abstract}
Rice (Oryza sativa) is the staple food in Sri Lanka. Being a country rich in biodiversity, over 3000 rice varieties have been reported in the country. This study was carried out to investigate the macronutrient composition and mineral composition of selected common traditional or heirloom rice varieties which were grown from ancient times in Sri Lanka. Six heirloom red pericarp rice varieties, one heirloom white pericarp rice variety, two genetically improved white pericarp rice varieties and one genetically improved red pericarp rice variety were collected representing all the agro-climatic zones of Sri Lanka. Five hundred grams each sample was cleaned, dehusked, ground and pooled to obtain a composite sample. The prepared rice samples were analyzed for measure the moisture, crude fat, crude protein, ash and total carbohydrate contents. Mineral composition was analyzed using inductive couple plasma mass spectrophotometry (ICPMS). The results indicated that all the rice varieties tested were significantly not different by their carbohydrate contents. Total carbohydrate contents varied from $65.80 \pm 0.79 \%$ to $79.30 \pm 0.38 \%$. Crude fat contents of rice varieties varied from $1.59 \pm 0.01 \%$ to $2.87 \pm 0.20 \%$, crude protein contents varied from $7.60 \pm 0.20 \%$ to $9.31 \pm 0.63 \%$, ash contents ranged from $0.84 \pm 0.03 \%$ to $2.95 \pm 0.01 \%$. Red pericarp rice varieties were richer in crude fat, protein, ash and minerals such as $\mathrm{Na}, \mathrm{Mg}, \mathrm{K}, \mathrm{Ca}, \mathrm{Al}, \mathrm{Cr}, \mathrm{Mn}, \mathrm{Fe}, \mathrm{Co}, \mathrm{Ni}, \mathrm{Cu}, \mathrm{Zn}, \mathrm{As}, \mathrm{Se}, \mathrm{Sn}, \mathrm{Li}$, $\mathrm{Be}, \mathrm{V}, \mathrm{Ga}, \mathrm{Rb}, \mathrm{Sr}, \mathrm{Mo}, \mathrm{Cd}, \mathrm{Ba}$ and $\mathrm{Bi}$ than white rice pericarp varieties. Further traditional rice varieties were richer in overall nutritional quality and in mineral composition compared to genetically improved white pericarp rice varieties. Traditional rice varieties are good sources to fulfill most of the daily mineral requirement of human. As an overall conclusion, red pericarp rice has more nutritional value than white pericarp rice. According to the results, some traditional varieties as well as red pericarp improved rice varieties are nutritionally important for human beings.
\end{abstract}

Keywords: agro-climatic zones, macronutrients, minerals, Traditional rice

\section{Introduction}

Rice (Oryza sativa) is the most important cereal cultivated in Sri Lanka. It has been the staple food and the backbone of Sri Lanka's agriculture since antiquity. The long history of rice cultivation, the wide range of ecoedaphic condition and various farming systems present in the country have resulted in Sri Lanka having a wide varietal diversity of rice. Over 3000 rice varieties have been reported in Sri Lanka (Helvetas, 2001).

According to Muthukuda Arachchi and Wijerathne (2007) rice exhibits a very high genetic diversity and now confined to gene banks amounting to about 4000 accessions including wild relatives land races, old cultivars etc. About $30 \%$ of the rice landraces cultivated in the past have not been collected and conserved. Five wild rice 
species O.nivara, O.rufipogon, O.eichingeri, O.rhizomatis and O.granulata are found in scattered places in the county and are in danger of extinction due to loss of habitats.

Whole grains are a rich source of vitamins, minerals, carbohydrates, fats, oils and protein. However, when refined by removing the bran and germ, the remaining endosperm is mostly carbohydrates and the other nutrients. As human food, cereals are usually marketed in raw grain form or as ingredients of food products (Sarwar et al. 2013).

Data on the composition of foods are essential for nutrition research, product development, nutrition education, trade of foods and food products between and within countries, estimating/comparing the nutrient content of foods, identifying sources of particular nutrients, analyzing individuals' diets, devising special diets for patients (e.g. heart disease, coeliac disease), analyzing dietary survey data, assessing how dietary intake affects health and disease outcomes, devising special diets for epidemiological research, monitoring food and nutrient availability, development of dietary guidelines, implementation and monitoring of food legislation, consumer information and education, preparing educational materials (e.g. for schools), food labeling and nutrient claims, marketing of products, recipe and menu development and analysis, devising special diets for healthy people with particular needs (e.g. athletes), completing missing values in a dataset, to assess overall dietary balance, to obtain a quantitative estimate of energy and/or specific nutrient intakes, to identify nutritional deficiencies or excesses, to assess the risk of malnutrition, to monitor compliance with dietary advice. and development of nutrition and agricultural policies by government agencies (Egan et al. 2007; Williamson \& Foundation, 2005; Rand et al. 1991)

This study was conducted to analyze the macronutrient composition of seven traditional rice varieties grown in Sri Lanka which includes six red rice varieties and one white rice variety. Moreover, three improved rice varieties including two white and one red rice varieties have analyzed to compare the macronutrient composition with traditional varieties.

\section{Materials and Methods}

\section{Chemicals}

$\mathrm{H}_{2} \mathrm{SO}_{4}$ (96\%, Sigma Aldrich), $\mathrm{NaOH}$ (100\%, Sigma Aldrich), Boric acid (99\%, Sigma Aldrich), Bromocrysol green (analytical grade, Sigma Aldrich), $40^{\circ} \mathrm{C}-60^{\circ} \mathrm{C}$ petroleum ether (analytical grade, Sigma Aldrich), $\mathrm{HCl}$ (95\%, Sigma Aldrich), Sodium carbonate (99\%, Sigma Aldrich) and Phenol (100\%, Sigma Aldrich)were purchased.

\section{Sampling Plan and Sample Collection}

Seven traditional/heirloom rice varieties in Sri Lanka were collected from main agro-climatic zones in Sri Lanka as shown in table 1. Three genetically improved rice varieties were collected from Rice Research Development Institute in Bathalegoda (IL) and Rice Research Station in Ambalanthota (DL) for the purpose of comparison of nutritional composition with traditional rice varieties. Six heirloom red pericarp rice varieties, one heirloom white pericarp rice variety, two genetically improved white pericarp rice varieties and one genetically improved red pericarp rice variety were collected for the analysis of nutritional composition.

Table 1: Proximate composition of different traditional rice varieties

\begin{tabular}{|c|c|c|c|c|c|c|c|}
\hline Rice Variety & WL & WM & WU & IL & IM & IU & DL \\
\hline Suwandel & $\sqrt{ }$ & $\checkmark$ & & $\checkmark$ & $\sqrt{ }$ & $x$ & $\checkmark$ \\
\hline Kalu Heenati & $\checkmark$ & $\checkmark$ & & $\checkmark$ & $\checkmark$ & $x$ & $\checkmark$ \\
\hline Kuruluthuda & $x$ & $\checkmark$ & & $\checkmark$ & $\checkmark$ & $x$ & $\checkmark$ \\
\hline Madathavalu & $\checkmark$ & $\checkmark$ & & $\checkmark$ & $\checkmark$ & $x$ & $\checkmark$ \\
\hline Pachchaperumal & $\checkmark$ & $\checkmark$ & & $\checkmark$ & $\checkmark$ & $x$ & $\checkmark$ \\
\hline
\end{tabular}




\begin{tabular}{lcccccc} 
Pokkali & $\checkmark$ & $\checkmark$ & $\checkmark$ & $\checkmark$ & $\times$ & $\checkmark$ \\
\hline Sudu Heenati & $\checkmark$ & $\checkmark$ & $\checkmark$ & $\checkmark$ & $\times$ & $\checkmark$ \\
\hline BG 360 & $\times$ & $\times$ & $\checkmark$ & $\times$ & $\times$ & $\checkmark$ \\
\hline BG 352 & $\times$ & $\times$ & $\checkmark$ & $\times$ & $\times$ & $\checkmark$ \\
\hline AT 360 & $\times$ & $\times$ & $\times$ & $\times$ & $\times$ & $\checkmark$ \\
\hline$\checkmark=$ Collected & = Not cultivated & $\times$ = Variety not available/ Could not find
\end{tabular}

$\mathrm{WL}=$ Wet Low, $\mathrm{WM}=$ Wet Mid, $\mathrm{WU}=$ Wet $\mathrm{Up}, \mathrm{IL}=$ Intermediate Low, $\mathrm{IM}=$ Intermediate Mid, $\mathrm{IU}=$ Intermediate Up, DL = Dry Low.

The samples were collected from institutions of Department of Agriculture and farmers' fields based on the availability of crops and one germplasm sample from Plant Genetic Resources Center, Gannoruwa, Sri Lanka. All the samples from each agro-climatic zone were collected which harvested during the Maha season of year 2015 and homogenized to obtain a laboratory sample and these were analyzed separately in triplicates. Samples collected are shown in Figure 1.

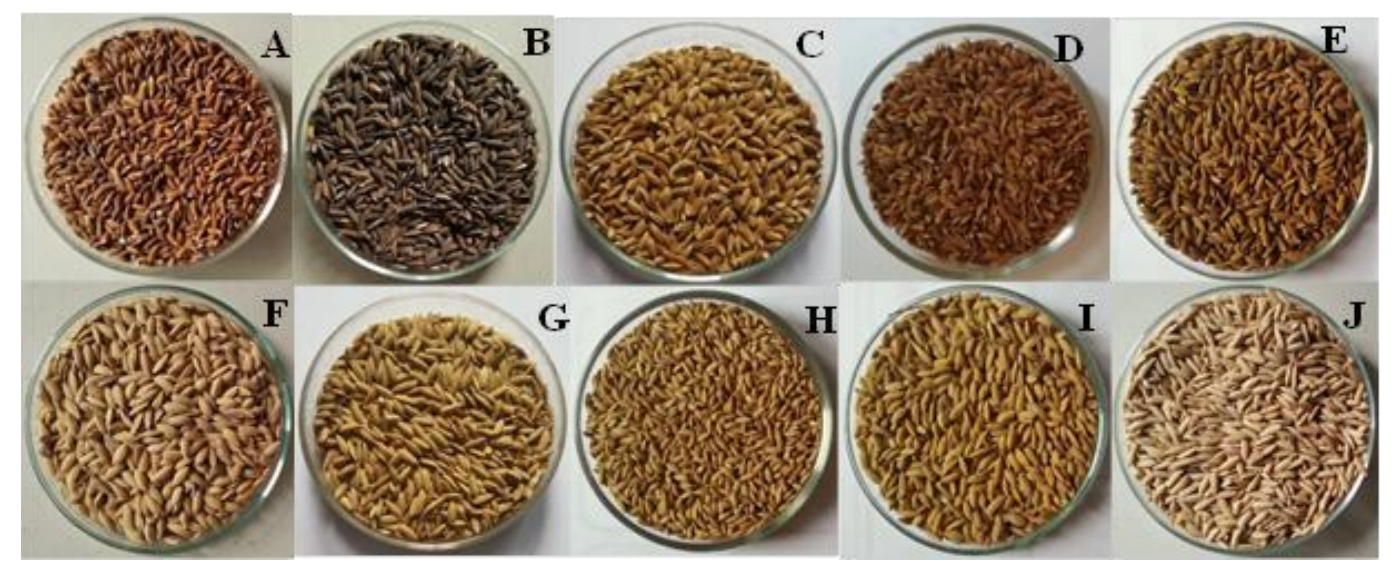

Figure 1: Rice (Oryza sativa) Samples Collected; A-Suwandel, B- Kaluheenati, CKuruluthuda, D-Madathavalu, E-Pachchaperumal, F-Pokkali, G-Suduheenati, H-BG 360, I-BG 352, J-AT 362

\section{Preparation of Rice Samples}

A total of $500 \mathrm{~g}$ of healthy, undamaged kernel were collected, sealed in polythene bags separately, labeled, placed in temperature controlled containers and transported to the laboratory without delay. Once the samples were received, they were photographed, cleaned and dehusked. Air dried rice kernels were ground by using a domestic grider (Apex, India) and stored under refrigerated conditions (LG-Express cool, Japan) at $5^{\circ} \mathrm{C}$ of temperature. After grinding was done equal amounts of samples received from each agro-climatic zone were pooled and homogenized to obtain a composite sample.

\section{Determination of the Proximate Composition}

Moisture content was analyzed according to AOAC 925:40:2000 method. Kjeldhal method was used to measure the crude protein content of prepared rice samples (AOAC 920:87:2000). Crude fat content was determined according to AOAC 920.39C:2000 method by using Soxhlet method. Ash content of the samples was determined using AOAC 923.03:2000 method. 


\section{Quantification of Total Carbohydrates}

Known amount of oven dried samples were hydrolyzed by keeping in boiling water bath for $3 \mathrm{~h}$ with $2.5 \mathrm{~mL}$ of $2.5 \mathrm{~N} \mathrm{HCl}$. Hydrolyzed samples were neutralized with sodium carbonate until effervescences ceased. Resulting solutions were brought up to $50 \mathrm{~mL}$ with distilled water. Prepared samples were centrifuged (Hitachi-Himac CT $4 \mathrm{D}$, Japan) at $4000 \mathrm{rpm}$ for 10 minutes.

Supernatants were collected and aliquots of $0.1 \mathrm{~mL}-0.2 \mathrm{~mL}$ were drawn of for analysis. Each tube was added with $1 \mathrm{~mL}$ of $5 \%$ phenol and $5 \mathrm{~mL}$ of $96 \%$ sulphuric acid and shaken well. After 10 minutes the contents were kept in a water bath at $25{ }^{\circ} \mathrm{C}-30^{\circ} \mathrm{C}$ for 20 minutes. Then the color was measured at $490 \mathrm{~nm}$ using UV visible spectrophotometer (Thermo Scientific-Genesys 10S, UK). The amounts of total carbohydrates present in samples were calculated using a standard graph generated using a series of standard glucose (Bartkiene, 2012).

\section{Analysis of Minerals using Inductive Couple Plasma Mass Spectroscopy (ICP-MS)}

Rice sample of $0.5 \mathrm{~g}$ was weighed accurately and added with $2 \mathrm{~mL}$ of Conc. Nitric acid and $2 \mathrm{~mL}$ of Conc. Hydrochloric acid. MARS 6 microwave digester was used for sample digestion. Samples were digested under 15 minutes of pre digestion time and 1 hour of total run time. Blank samples were digested for both digestion procedures without any sample. Once the digestion process was over samples were filtered and the volume was made up to $50 \mathrm{~mL}$ with deionized water. Digested samples were stored under frozen conditions (SISILIFC142LXX, Sri Lanka) at $-20^{\circ} \mathrm{C}$ of temperature.

Samples were analyzed by ICP-MS (Thermo Scientific-iCAPQ, UK) for $\mathrm{Na}, \mathrm{Mg}, \mathrm{K}, \mathrm{Ca}, \mathrm{Al}, \mathrm{Cr}, \mathrm{Mn}, \mathrm{Fe}, \mathrm{Co}$, Ni, $\mathrm{Cu}, \mathrm{Zn}, \mathrm{As}, \mathrm{Se}, \mathrm{Sn}, \mathrm{Li}, \mathrm{Be}, \mathrm{V}, \mathrm{Ga}, \mathrm{Rb}, \mathrm{Sr}, \mathrm{Mo}, \mathrm{Cd}, \mathrm{Ba}$ and Bi. An auto sampler (CETAC ASX-560) was used to inject the samples to ICP-MS. TM 25.4 (Environment Canada) for water reference was used to determine the accuracy of the analysis. Standards were used to develop standard curves for each mineral. Rh and Re were used as internal standards at $100 \mathrm{ppb}$ level.

\section{Results and Discussion}

\section{Proximate Composition of Traditional Rice Varieties}

Table 1 shows the proximate composition of different traditional rice varieties. Significantly, same moisture contents and significantly same total carbohydrate contents have resulted during analysis of selected traditional and improved rice varieties. Although all moisture contents were significantly same it seems improved varieties contained lower levels $(9.03 \pm 0.70 \%$ to $10.53 \pm 0.09 \%)$ of moisture contents compared to traditional varieties $(11.31 \pm 0.35 \%$ to $13.35 \pm 0.36)$. However, moisture content of rice depends on the rate of drying and method of drying used by the farmers after harvesting. Total carbohydrate content of analyzed varieties ranged from $64.87 \pm 0.08 \%$ to $77.26 \pm 0.62 \%$.

Crude fat content of the rice varieties analyzed except Suduheenati was not significantly different $(\mathrm{p}<0.05)$. Suduheenati consisted of $1.59 \pm 0.01 \%$ crude fat content while the fat contents of the other rice varieties ranged between $2.43 \pm 0.09 \%$ and $2.87 \pm 0.20 \%$ (Table no1).

Protein content of all the rice varieties varied from $7.60 \pm 0.20 \%$ to $9.31 \pm 0.63 \%$ with no significant difference. Pachchaperumal had the highest crude protein content $(9.31 \pm 0.63 \%)$ compared to other rice varieties. Crude protein content of all the other traditional rice varieties ranged from $7.60 \pm 0.20 \%$ to $9.31 \pm 0.63 \%$ while Pokkali possessed the least content of crude protein.

Table 1: Proximate composition of different traditional rice varieties

\begin{tabular}{cccccc}
\hline Rice Variety & Moisture \% & Crude Fat \% & Crude Protein \% & Ash \% & Total Carbohydrate $\%$ \\
\hline Suwandel & $11.31 \pm 0.35^{\mathrm{a}}$ & $2.84 \pm 0.02^{\mathrm{a}}$ & $8.76 \pm 0.28^{\mathrm{a}}$ & $1.41 \pm 0.64^{\mathrm{bc}}$ & $70.94 \pm 0.54^{\mathrm{a}}$ \\
\hline
\end{tabular}


Proceedings of $2^{\text {nd }}$ International Conference on Food Quality, Safety and Security, Vol. 1, 2018, pp. 1-8

\begin{tabular}{llllll}
\hline Kaluheenai & $12.07 \pm 0.13^{\mathrm{a}}$ & $2.43 \pm 0.07^{\mathrm{a}}$ & $8.11 \pm 0.15^{\mathrm{a}}$ & $1.97 \pm 0.04^{\text {bac }}$ & $65.80 \pm 0.79^{\mathrm{a}}$ \\
\hline Kuruluthuda & $11.75 \pm 0.05^{\mathrm{a}}$ & $2.58 \pm 0.27^{\mathrm{a}}$ & $7.92 \pm 0.15^{\mathrm{a}}$ & $2.95 \pm 0.01^{\mathrm{a}}$ & $69.67 \pm .04^{\mathrm{a}}$ \\
\hline Madathavalu & $12.57 \pm 0.55^{\mathrm{a}}$ & $2.74 \pm 0.33^{\mathrm{a}}$ & $7.79 \pm 0.32^{\mathrm{a}}$ & $2.16 \pm 0.38^{\mathrm{bac}}$ & $79.30 \pm 0.38^{\mathrm{a}}$ \\
\hline Pachchaperumal & $11.79 \pm 0.33^{\mathrm{a}}$ & $2.67 \pm 0.21^{\mathrm{a}}$ & $9.31 \pm 0.63^{\mathrm{a}}$ & $1.69 \pm 0.27^{\mathrm{bac}}$ & $70.42 \pm 0.52^{\mathrm{a}}$ \\
\hline Pokkali & $12.72 \pm 0.04^{\mathrm{a}}$ & $2.43 \pm 0.09^{\mathrm{a}}$ & $7.60 \pm 0.20^{\mathrm{a}}$ & $1.03 \pm 0.16^{\mathrm{bc}}$ & $77.26 \pm 0.62^{\mathrm{a}}$ \\
\hline Sudu Heenati & $13.35 \pm 0.36^{\mathrm{a}}$ & $1.59 \pm 0.01^{\mathrm{b}}$ & $7.91 \pm 0.08^{\mathrm{a}}$ & $0.93 \pm 0.03^{\mathrm{bc}}$ & $68.99 \pm 0.49^{\mathrm{a}}$ \\
\hline BG 360 & $9.03 \pm 0.70^{\mathrm{a}}$ & $2.87 \pm 0.20^{\mathrm{a}}$ & $7.92 \pm 0.04^{\mathrm{a}}$ & $0.84 \pm 0.03^{\mathrm{bc}}$ & $70.88 \pm 0.31^{\mathrm{a}}$ \\
\hline BG 352 & $9.55 \pm 0.48^{\mathrm{a}}$ & $2.55 \pm 0.27^{\mathrm{a}}$ & $7.91 \pm 0.67^{\mathrm{a}}$ & $1.74 \pm 0.58^{\text {bac }}$ & $71.73 \pm 0.81^{\mathrm{a}}$ \\
\hline AT 362 & $10.53 \pm 0.09^{\mathrm{a}}$ & $2.55 \pm 0.22^{\mathrm{a}}$ & $8.49 \pm 0.60^{\mathrm{a}}$ & $2.21 \pm 0.38^{\text {ba }}$ & $64.87 \pm 0.08^{\mathrm{a}}$ \\
\hline
\end{tabular}

*Data represent the mean of three replicates fresh weight basis. Values followed by the different superscript in each column are significantly different $(\mathrm{P}<0.05)$

Kuruluthuda contained the highest ash content of $2.95 \pm 0.01 \%$ followed by AT $362(2.21 \pm 0.38 \%)$. Kaluheenati, Madathavalu, Pachchaperumal and BG 352 contained $1.69 \pm 0.27 \%$ to $2.16 \pm 0.38 \%$ of ash contents. BG 360 , Suwandel, Pokkali and Suduheenati contained comparatively lower contents of ash contents compared to other rice varieties. The least ash content of traditional rice varieties was found in Suduheenati $0.93 \pm 0.03 \%$ and BG $360(0.84 \pm 0.03 \%)$ contained the least ash content among improved rice varieties. These results are in line with the results reported by few other researchers. (Samaranayake et al., 2017; Kariyawasam et al., 2016; Withanawasam, 2017)

According to the studies of Samaranayake et al. (2017) and Kariyawasam et al. (2016), the total carbohydrate content has ranged from $72 \pm 0.10 \%$ to $82.23 \pm 0.69 \%$ while the total carbohydrate content observed in the current study varied from $64.87 \pm 0.08 \%$ to $79.30 \pm 0.38 \%$. Although generated crude fat contents ranged between $1.59 \pm 0.01 \%$ and $2.87 \pm 0.20 \%$, the crude fat content of the above mentioned studies has varied from $2.3 \pm 0.00 \%$ to $3.28 \pm 0.04 \%$. The crude protein content ranged from $7.91 \%$ to $9.31 \pm 0.63 \%$ whereas Samaranayake et al (2017); Kariyawasam et al. (2016) and Withanawasam (2017) reported that the values ranged from $7.8 \%$ to $13.3 \%$. The ash content of rice ranged between $0.93 \pm 0.03 \%$ and $2.95 \pm 0.01 \%$.

\section{Mineral Composition of Traditional Rice Varieties}

Table 2 shows the mineral composition of analyzed rice varieties generated by ICP-MS analysis. Results have shown that Potassium, Magnesium, Sodium, Zinc, Manganese, Iron, Aluminium and Rubidium were available in higher amounts compared to other minerals considered during analysis of selected rice varieties. Potassium was the most abundant mineral found in all the varieties, which ranged from $2.03 \pm 0.04 \mathrm{mg} / \mathrm{g}$ to $2.38 \pm 0.01 \mathrm{mg} / \mathrm{g}$. Suduheenati contained the lowest Potassium level while Kuruluthuda comprised the highest amount of Potassium(Table 2).

Magnesium content of the rice varieties didn't elicit a great variation, except in Suwandel and Suduheenati which contained comparatively lower Magnesium levels. Kaluheenati consisted of the highest level of Magnesium content of $1.14 \pm 0.03 \mathrm{mg} / \mathrm{g}$ while $0.93 \pm 0.003 \mathrm{mg} / \mathrm{g}$ of lowest Magnesium content was found in Suduheenati. Sodium content of the samples varied between $0.03 \pm 0.005 \mathrm{mg} / \mathrm{g}$ and $0.07 \pm 0.007 \mathrm{mg} / \mathrm{g}$ while all the rice varieties contained the same level of sodium (Table 2).

Zinc and Manganese were the micro elements present at the highest levels in selected rice samples. The lowest Zinc level of $22.76 \pm 0.09 \mu \mathrm{g} / \mathrm{g}$ was found in Madathavalu while the highest amount of $34.40 \pm 0.03 \mu \mathrm{g} / \mathrm{g}$ was found in Kaluheenati. BG 352 contained the second highest Zinc level of $32.33 \pm 0.03 \mu \mathrm{g} / \mathrm{g}$. Suwandel, Pachchaperumal, Suduheenati, BG 360 and AT 362 contained significantly same amounts of Zinc. All the Zinc levels found were similar with results of Kariyawasam et al (2016).

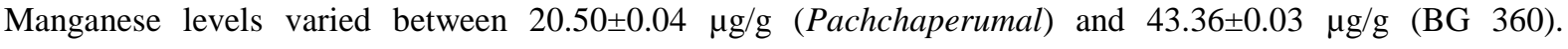
Furthermore, Kuruluthuda $(41.44 \pm 0.21 \mu \mathrm{g} / \mathrm{g})$ and BG 360 contained the same level of Manganese. Kaluheenati, 
Madathavalu, Pokkali and Suduheenati compromised similar amounts of Manganese levels varied between $27.24 \pm 0.06 \mu \mathrm{g} / \mathrm{g}$ to $28.86 \pm 0.01 \mu \mathrm{g} / \mathrm{g}$.

Kaluheenati, Pokkali and Suduheenati contained the highest levels of iron levels of $34.92 \pm 0.34 \mu \mathrm{g} / \mathrm{g}$, $34.92 \pm 0.03 \mu \mathrm{g} / \mathrm{g}$ and $31.29 \pm 0.27 \mu \mathrm{g} / \mathrm{g}$ respectively. Lower levels of Iron levels were found in Suwandel, Kuruluthuda, Pachchaperumal, BG 352 and AT 362. The lowest Iron content was found in Madathavalu $(16.58 \pm 0.09 \mu \mathrm{g} / \mathrm{g})$ and BG $360(18.95 \pm 0.02 \mu \mathrm{g} / \mathrm{g})$. All the Iron levels found were similar with results of Kariyawasam et al (2016).

The lowest aluminium content was found in BG $360(3.81 \pm 0.006 \mu \mathrm{g} / \mathrm{g})$ and the highest Aluminium level was detected in Pachchaperumal $(19.92 \pm 0.04 \mu \mathrm{g} / \mathrm{g})$. AT 362 and Kaluheenati contained 17.54 $\pm 0.008 \mu \mathrm{g} / \mathrm{g}$ and $16.60 \pm 0.02 \mu \mathrm{g} / \mathrm{g}$ of Aluminium contents which was much similar to that of Pachchaperumal. The next highly available micro mineral found was Rubidium. Kuruluthuda contained the highest Rubidium level of 19.37 \pm 0.04 $\mu \mathrm{g} / \mathrm{g}$ and $7.48 \pm 0.005 \mu \mathrm{g} / \mathrm{g}$ of lowest Rubidium level was detected in AT 362.

The highest calcium level found was $0.83 \pm 0.009 \mu \mathrm{g} / \mathrm{g}$ in BG 352 and the lowest was found in Madathavalu $(0.24 \pm 0.003 \mu \mathrm{g} / \mathrm{g})$. Kaluheenati, Suwandel and Pokkali contained same levels of Calcium $(0.43 \pm 0.006 \mu \mathrm{g} / \mathrm{g}$ $0.44 \pm 0.07 \mu \mathrm{g} / \mathrm{g})$. Kuruluthuda, Pachchaperumal and Suduheenati compromised of $0.33 \pm 0.008 \mu \mathrm{g} / \mathrm{g}$ to $0.30 \pm 0.006 \mu \mathrm{g} / \mathrm{g}$ of significantly same Calcium contents. Improved rice varieties contained significantly higher levels of Calcium compared to traditional varieties which ranged from $0.62 \pm 0.005 \mu \mathrm{g} / \mathrm{g}$ to $0.83 \pm 0.009 \mu \mathrm{g} / \mathrm{g}$ while this level was varied between $0.24 \pm 0.003 \mu \mathrm{g} / \mathrm{g}$ and $0.44 \pm 0.07 \mu \mathrm{g} / \mathrm{g}$ in traditional varieties.

The highest levels of Copper were found in Kaluheenati $(4.44 \pm 0.06 \mu \mathrm{g} / \mathrm{g})$. Pachchaperumal, AT 362 and Kuruluthuda were consisted the next highest Copper levels which were not significantly different. Lowest Copper levels were found in Suwandel, Pokkali, BG 360 and BG 352.

The highest Molybdenum contents were found in Kaluheenati and Pokkali. Pachchaperumal and AT 362 contained $0.82 \pm 0.003 \mu \mathrm{g} / \mathrm{g}$ and $0.86 \pm 0.0001 \mu \mathrm{g} / \mathrm{g}$ of next highest significantly same Molybdenum levels.

Nickel, Vanadium, Beryllium and Selenium contents of the selected rice varieties were same $(\mathrm{p}<0.05)$. The highest Cobalt content detected was $0.22 \pm 0.008 \mu \mathrm{g} / \mathrm{g}$ in BG 352. AT 352 and Pachchaperumal contained the lowest Cobalt levels of $0.05 \pm 0.004 \mu \mathrm{g} / \mathrm{g}$ and $0.06 \pm 0.003 \mu \mathrm{g} / \mathrm{g}$ respectively. Suduheenati contained $0.61 \pm 0.004$ $\mu \mathrm{g} / \mathrm{g}$ of highest Chromium level. Barium contents of the selected rice varieties were ranged between $2.61 \pm 0.008$ $\mu \mathrm{g} / \mathrm{g}$ and $8.64 \pm 0.008 \mu \mathrm{g} / \mathrm{g}$. The highest Barium content was found in BG 360 and the lowest in Pachchaperumal.

Suwandel, Kuruluthuda and Suduheenati were consisted significantly same amounts $(0.1 \mathrm{~g} / \mathrm{g})$ of Gallium while all the other rice varieties were contained significantly same levels of Gallium $(0.08 \mu \mathrm{g} / \mathrm{g})$. Suwnadel contained the highest level if Lithium content (Table 2).

Table 2: Mineral Composition of the Rice VarietiesTested

\begin{tabular}{|c|c|c|c|c|c|c|c|c|c|c|}
\hline $\begin{array}{l}\text { Minera } \\
1\end{array}$ & $\begin{array}{l}\text { Suwan } \\
\text { del }\end{array}$ & $\begin{array}{l}\text { Kaluhe } \\
\text { enati }\end{array}$ & $\begin{array}{l}\text { Kurulu } \\
\text { thuda }\end{array}$ & $\begin{array}{l}\text { Madath } \\
\text { avalu }\end{array}$ & $\begin{array}{l}\text { Pachcha } \\
\text { perumal }\end{array}$ & Pokkali & $\begin{array}{l}\text { Sudu } \\
\text { heenati }\end{array}$ & BG 360 & $\begin{array}{l}\mathrm{BG} \\
352\end{array}$ & AT 362 \\
\hline $\begin{array}{l}\mathrm{K} \\
(\mathrm{mg} / \mathrm{g})\end{array}$ & $\begin{array}{l}2.14 \pm 0 \\
.02^{\mathrm{abc}}\end{array}$ & $\begin{array}{l}2.24 \pm 0 \\
.04^{\mathrm{ab}}\end{array}$ & $\begin{array}{l}2.38 \pm 0 . \\
01^{\mathrm{a}}\end{array}$ & $\begin{array}{l}2.26 \pm 0 \\
001^{\mathrm{ab}}\end{array}$ & $\begin{array}{l}2.13 \pm 0 \\
02^{\mathrm{abc}}\end{array}$ & $\begin{array}{l}2.14 \pm 0 . \\
003^{\text {abc }}\end{array}$ & $\begin{array}{l}2.03 \pm 0 \\
.04^{\mathrm{c}}\end{array}$ & $\begin{array}{l}2.14 \pm 0 . \\
01^{\mathrm{bc}}\end{array}$ & $\begin{array}{l}2.25 \pm 0 \\
.03^{\mathrm{ab}}\end{array}$ & $\begin{array}{l}2.16 \pm 0 \\
03^{b c}\end{array}$ \\
\hline $\begin{array}{l}\mathrm{Mg} \\
(\mathrm{mg} / \mathrm{g})\end{array}$ & $\begin{array}{l}1.01 \pm 0 \\
.03^{\mathrm{ab}}\end{array}$ & $\begin{array}{l}1.14 \pm 0 \\
.03^{\mathrm{a}}\end{array}$ & $\begin{array}{l}1.50 \pm 0 . \\
04^{\mathrm{a}}\end{array}$ & $\begin{array}{l}1.03 \pm 0 . \\
003^{\mathrm{a}}\end{array}$ & $\begin{array}{l}1.09 \pm 0 \\
004^{\mathrm{a}}\end{array}$ & $\begin{array}{l}1.07 \pm 0 . \\
002^{\mathrm{a}}\end{array}$ & $\begin{array}{l}1.04 \pm 0 \\
.008^{\mathrm{b}}\end{array}$ & $\begin{array}{l}0.93 \pm 0 . \\
003^{\mathrm{a}}\end{array}$ & $\begin{array}{l}1.03 \pm 0 \\
.02^{\mathrm{a}}\end{array}$ & $\begin{array}{l}1.13 \pm 0 . \\
001^{\mathrm{a}}\end{array}$ \\
\hline $\begin{array}{l}\mathrm{Na} \\
(\mathrm{mg} / \mathrm{g})\end{array}$ & $\begin{array}{l}0.05 \pm 0 \\
.005^{\mathrm{a}}\end{array}$ & $\begin{array}{l}0.07 \pm 0 \\
.007^{\mathrm{a}}\end{array}$ & $\begin{array}{l}0.05 \pm 0 . \\
006^{\mathrm{a}}\end{array}$ & $\begin{array}{l}0.04 \pm 0 \\
001^{\mathrm{a}}\end{array}$ & $\begin{array}{l}0.06 \pm 0 . \\
001^{\mathrm{a}}\end{array}$ & $\begin{array}{l}0.03 \pm 0 \\
005^{\mathrm{a}}\end{array}$ & $\begin{array}{l}0.06 \pm 0 \\
.004^{\mathrm{a}}\end{array}$ & $\begin{array}{l}0.04 \pm 0 . \\
007^{\mathrm{a}}\end{array}$ & $\begin{array}{l}0.04 \pm 0 \\
.001^{\mathrm{a}}\end{array}$ & $\begin{array}{l}0.05 \pm 0 . \\
001^{\mathrm{a}}\end{array}$ \\
\hline $\begin{array}{l}\mathrm{Al} \\
(\mu \mathrm{g} / \mathrm{g})\end{array}$ & $\begin{array}{l}10.58 \pm \\
0.30^{\mathrm{de}}\end{array}$ & $\begin{array}{l}16.60 \pm \\
0.02^{\mathrm{ab}}\end{array}$ & $\begin{array}{l}10.25 \pm 0 \\
.05^{\mathrm{de}}\end{array}$ & $\begin{array}{l}11.57 \pm 0 \\
.03^{\mathrm{a}} \\
\end{array}$ & $\begin{array}{l}19.92 \pm 0 \\
.04^{\mathrm{ab}}\end{array}$ & $\begin{array}{l}9.46 \pm 0 \\
02^{\text {cd }}\end{array}$ & $\begin{array}{l}11.46 \pm \\
0.09^{\mathrm{a}}\end{array}$ & $\begin{array}{l}3.81 \pm 0 . \\
006^{\mathrm{f}}\end{array}$ & $\begin{array}{l}8.42 \pm 0 \\
.008^{\text {ef }}\end{array}$ & $\begin{array}{l}17.54 \pm 0 \\
.008^{\mathrm{ab}}\end{array}$ \\
\hline $\mathrm{Ca}$ & $0.44 \pm 0$ & $0.43 \pm 0$ & $0.33 \pm 0$ & $0.24 \pm 0$ & $0.30 \pm 0$ & $0.44 \pm 0$ & $0.32 \pm 0$ & $0.62 \pm 0$ & $0.83 \pm 0$ & $0.68 \pm 0$. \\
\hline
\end{tabular}


Proceedings of $2^{\text {nd }}$ International Conference on Food Quality, Safety and Security, Vol. 1, 2018, pp. 1-8

\begin{tabular}{|c|c|c|c|c|c|c|c|c|c|c|}
\hline$(\mu \mathrm{g} / \mathrm{g})$ & $.07^{\mathrm{bcd}}$ & $.006^{\text {bcd }}$ & $008^{\mathrm{cd}}$ & $003^{\mathrm{d}}$ & $006^{\mathrm{cd}}$ & $01^{b c d}$ & $.004^{\mathrm{cd}}$ & $005^{\mathrm{ab}}$ & $.009^{\mathrm{a}}$ & $002^{\mathrm{ab}}$ \\
\hline $\begin{array}{l}\mathrm{Zn} \\
(\mu \mathrm{g} / \mathrm{g})\end{array}$ & $\begin{array}{l}26.51 \pm \\
0.13^{\text {bc }}\end{array}$ & $\begin{array}{l}34.40 \pm \\
0.03^{\mathrm{ab}}\end{array}$ & $\begin{array}{l}28.39 \pm 0 \\
.34^{\mathrm{abc}}\end{array}$ & $\begin{array}{l}22.76 \pm 0 \\
.09^{c}\end{array}$ & $\begin{array}{l}23.63 \pm 0 \\
.08^{\mathrm{bc}}\end{array}$ & $\begin{array}{l}31.56 \pm 0 \\
.21^{\mathrm{abc}}\end{array}$ & $\begin{array}{l}25.63 \pm \\
0.07^{\text {bc }}\end{array}$ & $\begin{array}{l}27.57 \pm 0 \\
.04^{\mathrm{bc}}\end{array}$ & $\begin{array}{l}32.33 \pm \\
0.03^{\mathrm{a}}\end{array}$ & $\begin{array}{l}23.18 \pm 0 \\
.01^{\mathrm{bc}}\end{array}$ \\
\hline $\begin{array}{l}\mathrm{Cu} \\
(\mu \mathrm{g} / \mathrm{g})\end{array}$ & $\begin{array}{l}1.78 \pm 0 \\
.13^{\mathrm{d}}\end{array}$ & $\begin{array}{l}4.44 \pm 0 \\
.06^{\mathrm{a}}\end{array}$ & $\begin{array}{l}3.21 \pm 0 . \\
009^{\mathrm{ab}}\end{array}$ & $\begin{array}{l}2.19 \pm 0 . \\
01^{\text {cd }}\end{array}$ & $\begin{array}{l}3.70 \pm 0 . \\
001^{\mathrm{ab}}\end{array}$ & $\begin{array}{l}1.73 \pm 0 . \\
006^{\mathrm{d}}\end{array}$ & $\begin{array}{l}2.34 \pm 0 \\
.06^{\mathrm{bc}}\end{array}$ & $\begin{array}{l}1.86 \pm 0 . \\
02^{\mathrm{d}}\end{array}$ & $\begin{array}{l}1.41 \pm 0 \\
.004^{\mathrm{d}}\end{array}$ & $\begin{array}{l}3.54 \pm 0 . \\
001^{\mathrm{ab}}\end{array}$ \\
\hline $\begin{array}{l}\mathrm{Ni} \\
(\mu \mathrm{g} / \mathrm{g})\end{array}$ & $\begin{array}{l}0.36 \pm 0 \\
.001^{\mathrm{a}}\end{array}$ & $\begin{array}{l}0.46 \pm 0 \\
.006^{\mathrm{a}}\end{array}$ & $\begin{array}{l}0.43 \pm 0 . \\
003^{\mathrm{a}}\end{array}$ & $\begin{array}{l}0.17 \pm 0 \\
008^{\mathrm{a}}\end{array}$ & $\begin{array}{l}0.64 \pm 0 . \\
002^{\mathrm{a}}\end{array}$ & $\begin{array}{l}0.22 \pm 0 \\
001^{\mathrm{a}}\end{array}$ & $\begin{array}{l}0.28 \pm 0 \\
.003^{\mathrm{a}}\end{array}$ & $\begin{array}{l}0.13 \pm 0 . \\
000^{\mathrm{a}}\end{array}$ & $\begin{array}{l}0.20 \pm 0 \\
.006^{\mathrm{a}}\end{array}$ & $\begin{array}{l}0.20 \pm 0 . \\
001^{\mathrm{a}}\end{array}$ \\
\hline $\begin{array}{l}\text { Co } \\
(\mu \mathrm{g} / \mathrm{g})\end{array}$ & $\begin{array}{l}0.12 \pm 0 \\
.0003^{\mathrm{d}}\end{array}$ & $\begin{array}{l}0.14 \pm 0 \\
.005^{\mathrm{cd}}\end{array}$ & $\begin{array}{l}0.15 \pm 0 . \\
003^{\text {cd }}\end{array}$ & $\begin{array}{l}0.17 \pm 0 \\
008^{\text {abcd }}\end{array}$ & $\begin{array}{l}0.06 \pm 0 . \\
003^{\mathrm{e}}\end{array}$ & $\begin{array}{l}0.14 \pm 0 . \\
005^{\text {cd }}\end{array}$ & $\begin{array}{l}0.16 \pm 0 \\
.009^{\text {bcd }}\end{array}$ & $\begin{array}{l}0.22 \pm 0 \\
008^{\mathrm{a}}\end{array}$ & $\begin{array}{l}0.19 \pm 0 \\
.001^{\mathrm{abc}}\end{array}$ & $\begin{array}{l}0.05 \pm 0 \\
004^{\mathrm{e}}\end{array}$ \\
\hline $\begin{array}{l}\mathrm{Fe} \\
(\mu \mathrm{g} / \mathrm{g})\end{array}$ & $\begin{array}{l}21.85 \pm \\
0.89^{\mathrm{ab}}\end{array}$ & $\begin{array}{l}34.92 \pm \\
0.34^{\mathrm{a}}\end{array}$ & $\begin{array}{l}22.11 \pm 0 \\
.04^{\mathrm{ab}}\end{array}$ & $\begin{array}{l}16.58 \pm 0 \\
.09^{\mathrm{b}}\end{array}$ & $\begin{array}{l}27.27 \pm 0 \\
.05^{\mathrm{ab}}\end{array}$ & $\begin{array}{l}34.92 \pm 0 \\
.03^{\mathrm{a}}\end{array}$ & $\begin{array}{l}31.29 \pm \\
0.27^{\mathrm{a}}\end{array}$ & $\begin{array}{l}18.95 \pm 0 \\
.02^{\mathrm{b}}\end{array}$ & $\begin{array}{l}20.25 \pm \\
0.005^{\text {ab }}\end{array}$ & $\begin{array}{l}22.14 \pm 0 \\
.01^{\mathrm{ab}}\end{array}$ \\
\hline $\begin{array}{l}\mathrm{Mn} \\
(\mu \mathrm{g} / \mathrm{g})\end{array}$ & $\begin{array}{l}36.28 \pm \\
0.22^{\mathrm{b}}\end{array}$ & $\begin{array}{l}28.17 \pm \\
0.02^{\mathrm{c}}\end{array}$ & $\begin{array}{l}41.44 \pm 0 \\
.21^{\mathrm{a}}\end{array}$ & $\begin{array}{l}28.86 \pm 0 \\
.01^{\mathrm{c}}\end{array}$ & $\begin{array}{l}20.50 \pm 0 \\
.04^{\mathrm{d}}\end{array}$ & $\begin{array}{l}28.17 \pm 0 \\
.02^{\mathrm{c}}\end{array}$ & $\begin{array}{l}27.24 \pm \\
0.06^{\mathrm{c}}\end{array}$ & $\begin{array}{l}43.36 \pm 0 \\
.03^{\mathrm{a}}\end{array}$ & $\begin{array}{l}32.24 \pm \\
0.001^{\mathrm{b}}\end{array}$ & $\begin{array}{l}23.29 \pm 0 \\
.003^{\mathrm{d}}\end{array}$ \\
\hline $\begin{array}{l}\mathrm{Cr} \\
(\mu \mathrm{g} / \mathrm{g})\end{array}$ & $\begin{array}{l}0.42 \pm 0 \\
.01^{\mathrm{b}}\end{array}$ & $\begin{array}{l}0.32 \pm 0 \\
.005^{\mathrm{bc}}\end{array}$ & $\begin{array}{l}0.35 \pm 0 \\
002^{\text {bcd }}\end{array}$ & $\begin{array}{l}0.20 \pm 0 \\
001^{\mathrm{de}}\end{array}$ & $\begin{array}{l}0.23 \pm 0 . \\
001^{\text {cde }}\end{array}$ & $\begin{array}{l}0.32 \pm 0 \\
001^{\mathrm{bc}}\end{array}$ & $\begin{array}{l}0.61 \pm 0 \\
.004^{\mathrm{a}}\end{array}$ & $\begin{array}{l}0.12 \pm 0 \\
009^{\mathrm{e}}\end{array}$ & $\begin{array}{l}0.13 \pm 0 \\
.003^{\mathrm{e}}\end{array}$ & $\begin{array}{l}0.12 \pm 0 \\
006^{\mathrm{e}}\end{array}$ \\
\hline $\begin{array}{l}\mathrm{Ba} \\
(\mu \mathrm{g} / \mathrm{g})\end{array}$ & $\begin{array}{l}3.26 \pm 0 \\
.51^{\mathrm{ab}}\end{array}$ & $\begin{array}{l}2.70 \pm 0 \\
.13^{\mathrm{b}}\end{array}$ & $\begin{array}{l}3.71 \pm 0 . \\
04^{\text {ab }}\end{array}$ & $\begin{array}{l}3.13 \pm 0 . \\
01^{\mathrm{b}}\end{array}$ & $\begin{array}{l}2.75 \pm 0 . \\
05^{\mathrm{b}}\end{array}$ & $\begin{array}{l}2.70 \pm 0 . \\
01^{\mathrm{ab}}\end{array}$ & $\begin{array}{l}4.77 \pm 0 \\
.007^{\text {ab }}\end{array}$ & $\begin{array}{l}8.64 \pm 0 . \\
008^{\mathrm{a}}\end{array}$ & $\begin{array}{l}4.21 \pm 0 \\
.03^{\mathrm{ab}}\end{array}$ & $\begin{array}{l}2.61 \pm 0 . \\
008^{\mathrm{b}}\end{array}$ \\
\hline $\begin{array}{l}\mathrm{Cd} \\
(\mu \mathrm{g} / \mathrm{g})\end{array}$ & $\begin{array}{l}0.08 \pm 0 \\
.007^{\mathrm{c}}\end{array}$ & $\begin{array}{l}0.06 \pm 0 \\
.004^{\mathrm{c}}\end{array}$ & $\begin{array}{l}0.02 \pm 0 \\
0003^{\mathrm{a}}\end{array}$ & $\begin{array}{l}0.01 \pm 0 . \\
005^{\mathrm{b}}\end{array}$ & $\begin{array}{l}0.03 \pm 0 . \\
000^{\mathrm{d}}\end{array}$ & $\begin{array}{l}0.06 \pm 0 \\
004^{\mathrm{d}}\end{array}$ & $\begin{array}{l}0.07 \pm 0 \\
.002^{\mathrm{c}}\end{array}$ & $\begin{array}{l}0.08 \pm 0 \\
004^{\mathrm{bc}}\end{array}$ & $\begin{array}{l}0.01 \pm 0 \\
.0001^{\mathrm{d}}\end{array}$ & $\begin{array}{l}0.02 \pm 0 \\
0006^{\mathrm{a}}\end{array}$ \\
\hline $\begin{array}{l}\text { Mo } \\
(\mu \mathrm{g} / \mathrm{g})\end{array}$ & $\begin{array}{l}0.60 \pm 0 \\
.01^{\mathrm{cd}}\end{array}$ & $\begin{array}{l}1.10 \pm 0 \\
.001^{\mathrm{a}}\end{array}$ & $\begin{array}{l}0.50 \pm 0 . \\
0009^{d}\end{array}$ & $\begin{array}{l}0.53 \pm 0 . \\
001^{\mathrm{d}}\end{array}$ & $\begin{array}{l}0.82 \pm 0 \\
003^{b}\end{array}$ & $\begin{array}{l}1.10 \pm 0 . \\
001^{\mathrm{e}}\end{array}$ & $\begin{array}{l}0.61 \pm 0 \\
.001^{\mathrm{c}}\end{array}$ & $\begin{array}{l}0.66 \pm 0 \\
002^{c}\end{array}$ & $\begin{array}{l}0.60 \pm 0 \\
.0001^{\mathrm{cd}}\end{array}$ & $\begin{array}{l}0.86 \pm 0 \\
0001^{\mathrm{b}}\end{array}$ \\
\hline $\begin{array}{l}\mathrm{Sr} \\
(\mu \mathrm{g} / \mathrm{g})\end{array}$ & $\begin{array}{l}2.73 \pm 0 \\
.18^{\mathrm{de}}\end{array}$ & $\begin{array}{l}3.98 \pm 0 \\
.007^{\text {cd }}\end{array}$ & $\begin{array}{l}2.65 \pm 0 . \\
004^{\mathrm{de}}\end{array}$ & $\begin{array}{l}1.54 \pm 0 . \\
008^{\mathrm{e}}\end{array}$ & $\begin{array}{l}2.21 \pm 0 . \\
006^{\mathrm{e}}\end{array}$ & $\begin{array}{l}3.98 \pm 0 \\
007^{\mathrm{de}}\end{array}$ & $\begin{array}{l}2.57 \pm 0 \\
.006^{\mathrm{de}}\end{array}$ & $\begin{array}{l}6.14 \pm 0 . \\
002^{\mathrm{a}}\end{array}$ & $\begin{array}{l}4.96 \pm 0 \\
.002^{\mathrm{b}}\end{array}$ & $\begin{array}{l}5.04 \pm 0 . \\
001^{\mathrm{bc}}\end{array}$ \\
\hline $\begin{array}{l}\mathrm{Rb} \\
(\mu \mathrm{g} / \mathrm{g})\end{array}$ & $\begin{array}{l}13.33 \pm \\
0.06^{\mathrm{c}}\end{array}$ & $\begin{array}{l}10.29 \pm \\
0.02^{\mathrm{f}}\end{array}$ & $\begin{array}{l}19.37 \pm 0 \\
.04^{\mathrm{a}}\end{array}$ & $\begin{array}{l}13.48 \pm 0 \\
.05^{\mathrm{cd}}\end{array}$ & $\begin{array}{l}11.35 \pm 0 \\
.04^{\mathrm{ef}}\end{array}$ & $\begin{array}{l}10.29 \pm 0 \\
.002^{\text {cde }}\end{array}$ & $\begin{array}{l}16.38 \pm \\
0.03^{\mathrm{b}}\end{array}$ & $\begin{array}{l}11.83 \pm 0 \\
.005^{\mathrm{def}}\end{array}$ & $\begin{array}{l}10.53 \pm \\
0.003^{\mathrm{f}}\end{array}$ & $\begin{array}{l}7.48 \pm 0 . \\
005^{\mathrm{g}}\end{array}$ \\
\hline $\begin{array}{l}\mathrm{Ga} \\
(\mu \mathrm{g} / \mathrm{g})\end{array}$ & $\begin{array}{l}0.11 \pm 0 \\
.008^{\mathrm{ab}}\end{array}$ & $\begin{array}{l}0.08 \pm 0 \\
.003^{\mathrm{abc}}\end{array}$ & $\begin{array}{l}0.11 \pm 0 . \\
004^{\mathrm{ab}}\end{array}$ & $\begin{array}{l}0.08 \pm 0 \\
001^{\mathrm{abc}}\end{array}$ & $\begin{array}{l}0.08 \pm 0 \\
002^{\mathrm{abc}}\end{array}$ & $\begin{array}{l}0.08 \pm 0 \\
003^{\mathrm{abc}}\end{array}$ & $\begin{array}{l}0.10 \pm 0 \\
.001^{\mathrm{ab}}\end{array}$ & $\begin{array}{l}0.10 \pm 0 . \\
005^{\mathrm{ab}}\end{array}$ & $\begin{array}{l}0.08 \pm 0 \\
.002^{\mathrm{abc}}\end{array}$ & $\begin{array}{l}0.08 \pm 0 . \\
0006^{\text {abc }}\end{array}$ \\
\hline $\begin{array}{l}\mathrm{V} \\
(\mu \mathrm{g} / \mathrm{g})\end{array}$ & $\begin{array}{l}0.08 \pm 0 \\
.005^{\mathrm{a}}\end{array}$ & $\begin{array}{l}0.15 \pm 0 \\
.03^{\mathrm{a}}\end{array}$ & $\begin{array}{l}0.05 \pm 0 . \\
004^{\mathrm{a}}\end{array}$ & $\begin{array}{l}0.03 \pm 0 \\
004^{\mathrm{a}}\end{array}$ & $\begin{array}{l}0.05 \pm 0 . \\
003^{\mathrm{a}}\end{array}$ & $\begin{array}{l}0.15 \pm 0 \\
003^{\mathrm{a}}\end{array}$ & $\begin{array}{l}0.15 \pm 0 \\
.001^{\mathrm{a}}\end{array}$ & $\begin{array}{l}0.07 \pm 0 . \\
003^{\mathrm{a}}\end{array}$ & $\begin{array}{l}0.14 \pm 0 \\
.002^{\mathrm{a}}\end{array}$ & $\begin{array}{l}0.19 \pm 0 . \\
0005^{\mathrm{a}}\end{array}$ \\
\hline $\begin{array}{l}\mathrm{Be} \\
(\mu \mathrm{g} / \mathrm{g})\end{array}$ & $\begin{array}{l}0.001 \pm \\
0.00^{\mathrm{a}}\end{array}$ & $\begin{array}{l}0.009 \pm \\
0.000^{\mathrm{a}}\end{array}$ & $\begin{array}{l}0.002 \pm 0 \\
.000^{\mathrm{a}}\end{array}$ & $\begin{array}{l}0.003 \pm 0 \\
.000^{\mathrm{a}}\end{array}$ & $\begin{array}{l}0.004 \pm 0 \\
.000^{\mathrm{a}}\end{array}$ & $\begin{array}{l}0.002 \pm 0 \\
.000^{\mathrm{a}}\end{array}$ & $\begin{array}{l}0.003 \pm \\
0.000^{\mathrm{a}}\end{array}$ & $\begin{array}{l}0.002 \pm 0 \\
.000^{\mathrm{a}}\end{array}$ & $\begin{array}{l}0.001 \pm \\
0.000^{\mathrm{a}}\end{array}$ & $\begin{array}{l}0.002 \pm 0 \\
.000^{\mathrm{a}}\end{array}$ \\
\hline $\begin{array}{l}\mathrm{Li} \\
(\mu \mathrm{g} / \mathrm{g})\end{array}$ & $\begin{array}{l}0.19 \pm 0 \\
.008^{\mathrm{ab}}\end{array}$ & $\begin{array}{l}0.03 \pm 0 \\
.002^{\mathrm{b}}\end{array}$ & $\begin{array}{l}0.01 \pm 0 \\
000^{\mathrm{b}}\end{array}$ & $\begin{array}{l}0.16 \pm 0 \\
005^{\mathrm{ab}}\end{array}$ & $\begin{array}{l}0.17 \pm 0 . \\
004^{\mathrm{ab}}\end{array}$ & $\begin{array}{l}0.03 \pm 0 \\
002^{\mathrm{ab}}\end{array}$ & $\begin{array}{l}0.31 \pm 0 \\
.001^{\mathrm{a}}\end{array}$ & $\begin{array}{l}0.04 \pm 0 \\
0003^{b}\end{array}$ & $\begin{array}{l}0.03 \pm 0 \\
.0003^{\mathrm{b}}\end{array}$ & $\begin{array}{l}0.17 \pm 0 \\
009^{\mathrm{ab}}\end{array}$ \\
\hline $\begin{array}{l}\text { Sn } \\
(\mu \mathrm{g} / \mathrm{g})\end{array}$ & $\begin{array}{l}0.01 \pm 0 \\
.0001^{\mathrm{b}}\end{array}$ & $\begin{array}{l}0.013 \pm \\
0.000^{\mathrm{ab}}\end{array}$ & $\begin{array}{l}0.01 \pm 0 . \\
000^{\mathrm{ab}}\end{array}$ & $\begin{array}{l}0.03 \pm 0 \\
000^{\mathrm{ab}}\end{array}$ & $\begin{array}{l}0.03 \pm 0 . \\
007^{\mathrm{ab}}\end{array}$ & $\begin{array}{l}0.01 \pm 0 \\
000^{\mathrm{a}}\end{array}$ & $\begin{array}{l}0.03 \pm 0 \\
.001^{\mathrm{ab}}\end{array}$ & $\begin{array}{l}0.02 \pm 0 . \\
000^{\mathrm{ab}}\end{array}$ & $\begin{array}{l}0.02 \pm 0 \\
.005^{\mathrm{ab}}\end{array}$ & $\begin{array}{l}0.01 \pm 0 . \\
0003^{\mathrm{ab}}\end{array}$ \\
\hline $\begin{array}{l}\text { Se } \\
(\mu \mathrm{g} / \mathrm{g})\end{array}$ & $\begin{array}{l}0.12 \pm 0 \\
.0003^{\mathrm{a}}\end{array}$ & $\begin{array}{l}0.09 \pm 0 \\
.000^{\mathrm{a}}\end{array}$ & $\begin{array}{l}0.05 \pm 0 . \\
0003^{\mathrm{a}}\end{array}$ & $\begin{array}{l}0.07 \pm 0 \\
000^{\mathrm{a}}\end{array}$ & $\begin{array}{l}0.06 \pm 0 . \\
002^{\mathrm{a}}\end{array}$ & $\begin{array}{l}0.09 \pm 0 . \\
000^{\mathrm{a}}\end{array}$ & $\begin{array}{l}0.07 \pm 0 \\
.004^{\mathrm{a}}\end{array}$ & $\begin{array}{l}0.08 \pm 0 . \\
004^{\mathrm{a}}\end{array}$ & $\begin{array}{l}0.05 \pm 0 \\
.000^{\mathrm{a}}\end{array}$ & $\begin{array}{l}0.04 \pm 0 . \\
0001^{\mathrm{a}}\end{array}$ \\
\hline $\begin{array}{l}\text { As } \\
(\mu \mathrm{g} / \mathrm{g})\end{array}$ & $\begin{array}{l}0.05 \pm 0 \\
.0005^{\mathrm{cd}}\end{array}$ & $\begin{array}{l}0.04 \pm 0 \\
.000^{\mathrm{ab}}\end{array}$ & $\begin{array}{l}0.03 \pm 0 . \\
000^{\mathrm{ab}}\end{array}$ & $\begin{array}{l}0.01 \pm 0 \\
0001^{\mathrm{ab}}\end{array}$ & $\begin{array}{l}0.04 \pm 0 . \\
001^{\mathrm{ab}}\end{array}$ & $\begin{array}{l}0.05 \pm 0 \\
002^{\text {cd }}\end{array}$ & $\begin{array}{l}0.05 \pm 0 \\
.005^{\text {cd }}\end{array}$ & $\begin{array}{l}0.06 \pm 0 . \\
005^{\mathrm{a}}\end{array}$ & $\begin{array}{l}0.05 \pm 0 \\
.004^{\text {cd }}\end{array}$ & $\begin{array}{l}0.02 \pm 0 \\
0001^{\mathrm{ab}}\end{array}$ \\
\hline
\end{tabular}

*Data represent the mean of three replicates fresh weight basis. Values followed by the different superscript in each raw are significantly different $(\mathrm{P}<0.05)$

All the improved rice varieties contained the highest Strontium levels. BG 360 consisted $6.14 \pm 0.002 \mu \mathrm{g} / \mathrm{g}, \mathrm{BG}$ 352 contained $4.96 \pm 0.002 \mu \mathrm{g} / \mathrm{g}$ and AT 362 compromised with $5.04 \pm 0.001 \mu \mathrm{g} / \mathrm{g}$ of Strontium contents. Both Pokkali and Kaluheenati were consisted with $3.98 \pm 0.007 \mu \mathrm{g} / \mathrm{g}$ of highest Strontium level over other traditional rice varieties (Table 2).

Kariyawasam et al. (2016) have found that Lead, Arsenic and Cadmium levels of Pokkali, Kaluheenati and some other Sri Lankan traditional rice varieties have existed below $0.04 \mathrm{ppm}, 0.02 \mathrm{ppm}$ and $0.01 \mathrm{ppm}$ respectively, which may not cause heavy metal toxicity due to Arsenic, Cadmium or Lead. All the Arsenic and Cadmium levels found in this study remained close to the data generated by Kariyawasam et al (2016).

Humans need a certain daily intake of food supplements (Lenntech, 2017). Daily rice intake in Sri Lanka 255g/day (Abdullah et al., 2006) Lenntech (2017) has summarizes recommended daily intakes by various health experts and agencies in order to provide an overview of recommended daily allowances of all minerals. It 
perfectly shows that traditional rice varieties in Sri Lanka possess considerable amount of minerals that can fulfill the daily mineral requirement of human.

\section{Conclusions}

Red pericarp rice varieties were richer in crude fat, protein, ash and minerals such as $\mathrm{Na}, \mathrm{Mg}, \mathrm{K}, \mathrm{Ca}, \mathrm{Al}, \mathrm{Cr}, \mathrm{Mn}$, $\mathrm{Fe}, \mathrm{Co}, \mathrm{Ni}, \mathrm{Cu}, \mathrm{Zn}$, As, Se, Sn, Li, Be, V, Ga, Rb, Sr, Mo, Cd, Ba and Bi than white rice pericarp varieties. Pachchaperumal was the richest rice variety in nutrients and minerals out of all the rice varities considered. Further traditional rice varieties were richer in all the nutrients and minerals analyzed compared to genetically improved white pericarp rice varieties. Traditional rice varieties are good sources for fulfill most of the daily mineral requirement of human. As an overall conclusion, red pericarp rice has more nutritional value than white pericarp rice. According to the results, some traditional varieties as well as red pericarp improved rice varieties are nutritionally important for human beings.

\section{Acknowledgements}

The United Nations Environment Program and Food and Agriculture Organization of United Nations are acknowledged for funding the project. Plant Genetic Resource Center, Department of Agriculture, Sri Lanka is acknowledged for authenticating the samples and for providing samples.

\section{References}

Abdullah, A., Ito, S. \& Adhana, K., 2006. Estimate of rice consumption in Asian countries and the world towards 2050.on Rice in the World at, 1960, pp.28-43. Available at: http://worldfood2.apionet.or.jp/alias.pdf.

AOAC., 2000. Official Methods of Analysis. Association of Official. Analytical Chemists, Washington, D.C. USA.

Bartkiene, E., 2012. Plant Food analysis methods. , pp.1-70.

Egan, M.B. et al., 2007. The importance of harmonizing food composition data across Europe. Europoean Journal of Clinical Nutrition, (61), pp.813-821.

Elmadfa, I. \& Meyer, A.L., 2010. Importance of food composition data to nutrition and public health. European Journal of Clinical Nutrition, 64(S3), pp.S4-S7. Available at: http://dx.doi.org/10.1038/ejcn.2010.202.

Helvetas Sri Lanka, 2001. Sustainable_Farming_System_book.pdf, Helvetas Sri Lanka.

Kariyawasam, T.I.,Godakumbura, P.I.,Prashantha, M.A.B.,Premakumara, G.A.S., $2016 . \quad$ Proximate Composition, Calorie Content and Heavy Metals (As, Cd, Pb) of Selected Sri Lankan Traditional Rice (Oryza Sativa L.) Varieties. Procedia Food Science, 6(Icsusl 2015), pp.253-256. Available at: http://linkinghub.elsevier.com/retrieve/pii/S2211601X16000377.

Lenntech, B.V, 2017. Recommended daily intake of vitamins and minerals. , pp.1-2. Available at: http://www.lenntech.com/recommended-daily-intake.htm.

Muthukuda Arachchi, D.H , Wijerathne, P.M., 2007. Country report on the state of plant genetic resources for food and agriculture.

Rand, W.M, Pennington, J.A.T., Murphy, P., Klensin, J.C., 1991. Compiling Data for Food Composition Data Bases. , pp.1-65.

Samaranayake M.D.W., Yathursan S., Abeysekera W.K.S.M., H.H.M.T., 2017. NUTRITIONAL AND ANTIOXIDANT PROPERTIES OF SELECTED. Sri Lankan Journal of Biology, 2(June), pp.25-35.

Sarwar, M.H. et al., 2013. The importance of cereals ( Poaceae: Gramineae ) nutrition in human health: A review. Jounal of Cereals and Oil Seeds, 4(June), pp.32-35.

Williamson, B.C.,2005. Synthesis report No 2 : The Different Uses of Food Composition Databases. , (2).

Withanawasam, D.M., 2017. Heritage of Heirloom Rice varieties of Sri Lanka. 